Scientific Review - Engineering and Environmental Sciences (2021), 30 (2), 293-303

Sci. Rev. Eng. Env. Sci. (2021), 30 (2)

Przegląd Naukowy - Inżynieria i Kształtowanie Środowiska (2021), 30 (2), 293-303

Prz. Nauk. Inż. Kszt. Środ. (2021), 30 (2)

http://iks.pn.sggw.pl

DOI 10.22630/PNIKS.2021.30.2.25

Manar Al-JETHELAH, Hussam DEYAB, Tadahmun YASEEN

Tikrit University, College of Engineering

\title{
Thermal performance of novel indirect passive solar dryer
}

Key words: solar dryer, passive, flat collector, efficiency

\section{Introduction}

Drying crops under the sun is a popular method among farmers due to its low cost (Sreekumar, Manikantan \& Vijayakumar, 2008; Montero, Blanco, Miranda, Rojas \& Celma, 2010; Puglia, Rizzo, Morselli \& Tartarini, 2019). However, drying under sun is uncontrolled, and time-consuming. Furthermore, the sun-dried products could be damaged by animals and contaminated (Bansal, 1987). As a result, the need for solar dryers is key. The concept of solar dryer is to heat air that is passed over/through a wet crop. The moisture concentration difference between the heated air and the wet crop results in moisture evaporation from the wet crop to the heated air. Solar dryers are categorized into direct solar dryer, indirect solar dryer, and mixed solar dryer. This classification is based on the way that the solar dryer receives the solar radiation. The solar dryer performance and improving it have become under consideration of many researchers. Othieno, Grainger and Twidell (1982) dried maize in indirect solar dryer. The moisture content of the maize was decreased $8 \%$ in three days. Ameri, Hanini, Benhamou and Chibane (2018) found that the indirect solar dryer showed better thermal performance than the direct one. Lingayat, Chandramohan and Raju (2017) concluded that the humidity and velocity of the drying air played a significant role to improve the solar dryer performance. Maiti, Patel, Vijas, Eswaran and Ghosh (2011) added to the solar dryer reflectors which improved the efficiency by $18.5 \%$. El-Sebaii, AboulEnein, Ramadan and El-Gohary (2002) added a storage system to indirect solar dryer. Twelve hours earlier, the equilibrium moisture content of seedless grapes, $18 \%$, was gained by using the storage system.

The present experimental investigation proposes a novel solar dryer design. The proposed solar dryer design has two 
connected units. The first unit is a solar air heater, flat plate collector. The second unit is a drying chamber. Three walls of the drying chamber were designed as solar radiation receivers, i.e. flat plates covered with glass. Using this design not only ensures larger receiving area, but also the solar dryer faces the sun from three directions; the east, the south, and the west; rather than only from the South. As a reference, a conventional indirect solar dryer was also constructed and studied. The conventional indirect solar dryer consists of a solar air heater, flat plate collector, and an opaque drying chamber. The experimental study was performed in Tikrit city - Iraq $\left(34^{\circ} 40^{\prime} \mathrm{N}\right.$, $\left.43^{\circ} 39^{\prime} \mathrm{E}\right)$.

\section{Construction of the solar dryers and measuring devices}

The components of the studied solar dryers are described in this section. Furthermore, the details of the measuring devices are reported.

\section{Solar dryer design}

Both the proposed and conventional solar dryers consist of two main apparatuses, i.e. solar collector and drying chamber (Fig. 1). The novel proposed design is represented in the drying chamber walls. In the conventional solar dryer, the drying chamber walls are opaque and thermally insulated. While three walls of the proposed drying chamber; left, front, and right walls; are solar collectors.

\section{Solar collector}

The design of the solar collector for both dryers was similar. The solar collector was a flat plate of area $0.75 \mathrm{~m}^{2}$ directed to the south. The solar collectors were fixed in front of the drying chambers. The collector was $40^{\circ}$ inclined from horizon facing the south. The collector consists of a flat plate made from a sheet of aluminium as an absorber. The absorber was painted with a matt black colour to enhance its ability to absorb thermal radiation. The absorber was covered with a glass, $0.004 \mathrm{~m}$ thickness. To give the drying air space to naturally flow over the absorber through the collector, a gap of $0.05 \mathrm{~m}$ was left between the absorber and the glass. The sides and bottom of the solar collector were thermally insulated with a $0.05 \mathrm{~m}$ thickness of cork. The internal and external dimensions of the solar collector were $1 \times 0.75 \times 0.07 \mathrm{~m}$ and $1 \times 0.85 \times 0.12 \mathrm{~m}$, respectively. The role of the solar collector is to provide heat, by absorbing solar radiation, to warmth the drying air before entering the drying chamber.

\section{Drying chamber}

Both solar dryers had a drying chamber. The drying chamber specifications are listed in Table 1 . The drying chamber was constructed from light aluminium sheets and frames. To connect the drying chamber to the solar collector, a rectangular duct was used. In each chamber, three movable trays, wire-mesh, were used. At the top of each chamber, a cylindrical galvanized chimney was attached. The back of the drying chamber was used as a door. The other drying chamber walls; 
a

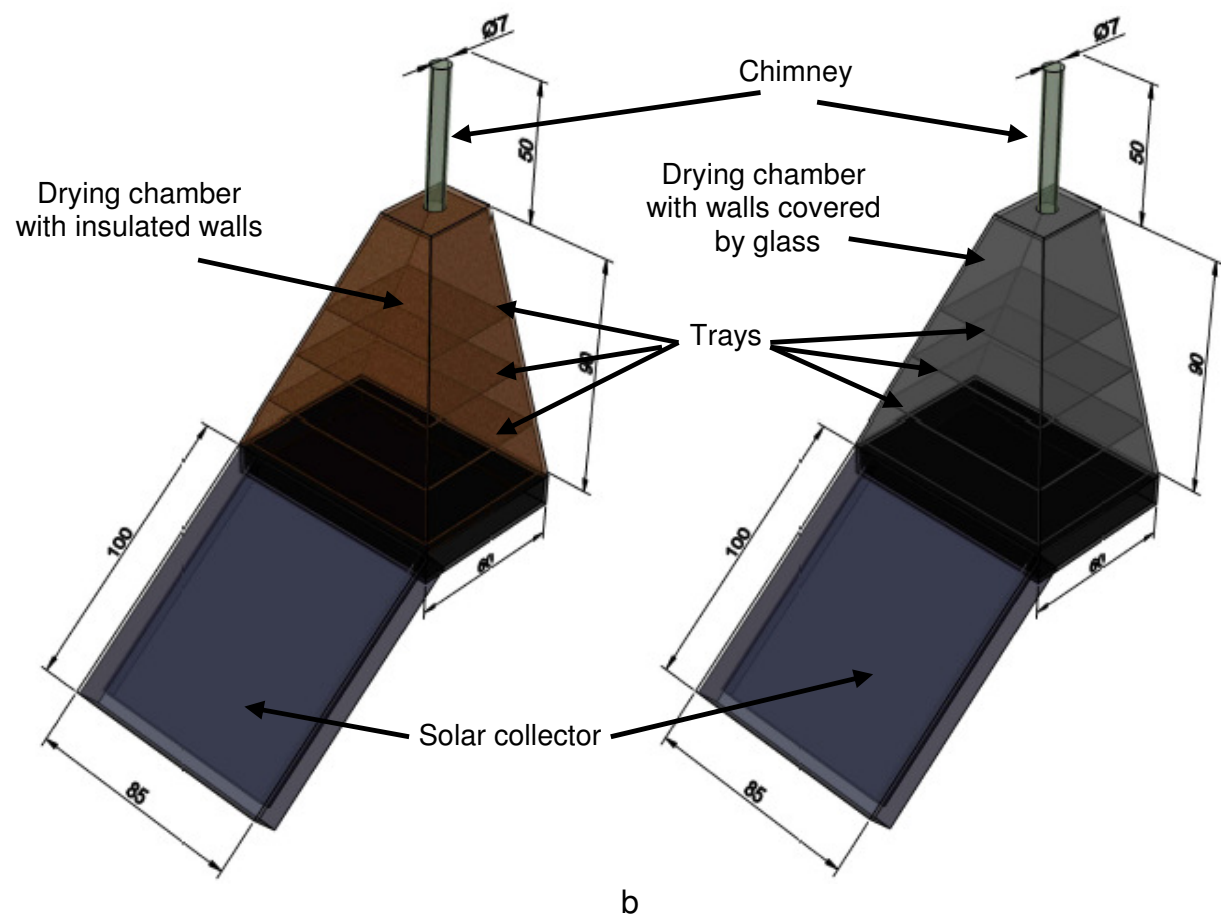

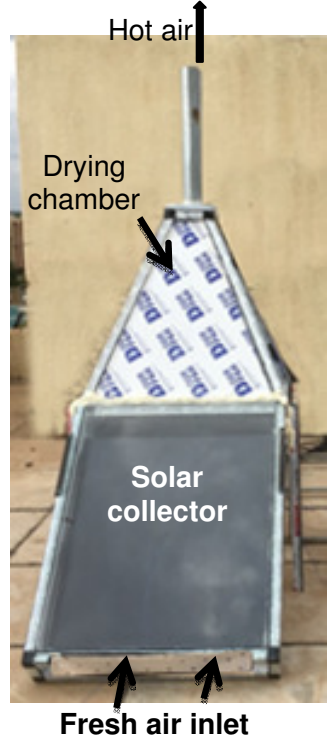

Conventional indirect solar dryer

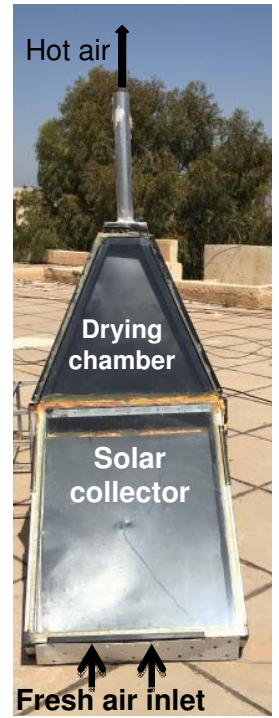

Novel indirect solar dryer

FIGURE 1. Novel solar dryer: a - three-dimensional configuration and dimensions (all dimensions in $\mathrm{cm}) ; \mathrm{b}$ - the experimental test rig 
TABLE 1. Drying chamber specifications

\begin{tabular}{|c|c|c|c|c|}
\hline \multirow{2}{*}{ Component } & \multicolumn{3}{|c|}{ Dimensions $[\mathrm{m}]$} & \multirow{2}{*}{ Material } \\
\hline & base & top & width & \\
\hline \multicolumn{5}{|c|}{ Conventional dryer drying chamber walls: } \\
\hline front and back & 0.85 & 0.21 & 0.93 & \multirow{2}{*}{$\begin{array}{c}\text { aluminium sheets } \\
\text { covered } \\
\text { by } 20-\mathrm{mm} \text { thick of cork }\end{array}$} \\
\hline right and left & 0.60 & 0.28 & 0.93 & \\
\hline \multicolumn{5}{|l|}{ Novel dryer drying chamber walls: } \\
\hline back & 0.85 & 0.21 & 0.93 & $\begin{array}{c}\text { aluminium sheets } \\
\text { covered } \\
\text { by } 20 \text {-mm thick of cork }\end{array}$ \\
\hline front & 0.85 & 0.21 & 0.93 & \multirow{2}{*}{$\begin{array}{l}\text { aluminium sheets coated } \\
\text { with black and covered } \\
\text { by 4-mm thick of glass }\end{array}$} \\
\hline left and right & 0.60 & 0.28 & 0.93 & \\
\hline $\begin{array}{l}\text { Duct, connects the solar collector } \\
\text { with the drying chamber }\end{array}$ & \multicolumn{3}{|c|}{$0.75 \times 0.07$} & aluminium \\
\hline Chimney & \multicolumn{3}{|c|}{ 0.07-diameter, 0.5 -height } & aluminium \\
\hline
\end{tabular}

left, front, and right walls; were inclined by $75^{\circ}$. For the conventional solar dryer, all the drying chambers walls including the door were thermally insulated with cork. For the novel solar dryer, only the door was thermally insulated with cork. The left, front, and right walls were coated with matt black colour and covered with $4 \mathrm{~mm}$ thick glass. A space of $5 \mathrm{~mm}$ was left between the wall and the glass (Dheyab, Al-Jethelah, Yassen \& Khalil, 2019). As a result, the three walls became solar collectors.

\section{Measuring devices}

The measured data in the present work were solar radiation and temperatures. The solar radiation was measured using a solar digital meter daystar. inc DS-05A type was used with a relative uncertainty of $\pm 3 \%$, resolution of $1 \mathrm{~W} \cdot \mathrm{m}^{-2}$, and range of $0-1,200 \mathrm{~W} \cdot \mathrm{m}^{-2}$. The velocity of air leaving the drying chamber was measured using BENETECH GM8 16C anemometer with an accuracy of $\pm 0.1 \mathrm{~m} \cdot \mathrm{s}^{-1}$. To measure the temperatures, K-type thermocouple wires with an uncertainty of $\pm 0.1^{\circ} \mathrm{C}$ were used. The used data logger was of type Applent AT4808 with an uncertainty of $\pm 0.2 \%+1{ }^{\circ} \mathrm{C}$, resolution of $0.1^{\circ} \mathrm{C}$, and temperature range from -200 to $1,300^{\circ} \mathrm{C}$. The relative uncertainties of the measured and calculated parameters are listed in Table 2.

TABLE 2. The relative uncertainty of the measured and calculated parameters

\begin{tabular}{|l|c|}
\hline Parameter & $\begin{array}{c}\text { Relative } \\
\text { uncertainty } \\
{[\%]}\end{array}$ \\
\hline Temperature-thermocouple & 0.10 \\
\hline Temperature - data logger & 1.15 \\
\hline Air velocity & 5.56 \\
\hline Solar radiation meter & 3.00 \\
\hline Thermal efficiency & 0.03 \\
\hline
\end{tabular}




\section{Experimental procedure}

The experimental set-ups were oriented toward the south. The solar collector was always exposed and never been covered. In this way, the solar collector absorber was heated by the solar radiation before starting the experiments. The experiments were conducted from 9:00 to $15: 00$. At the head of each hour, the solar radiation, air velocity leaving the drying chamber, and the temperatures at the aforementioned locations were recorded.

\section{Energy analysis}

The solar dryers are used to produce hot air, from the solar radiation, then use it to dry crops. The thermal an energy balance of the solar dryer is

$I=Q_{u}+Q_{s t}+Q_{l}$

where:

$I$ - solar radiation,

$Q_{u}$ - useful thermal energy,

$Q_{s t}-$ stored energy,

$Q_{l}$ - thermal loss.

Since the stored energy in this work is zero, Eq. (1) becomes

$Q_{u}=Q_{s}-Q_{l}$

The useful heat is expressed as

$Q_{u}=\dot{m} c_{p}\left(T_{o}-T_{i}\right)$

where:

$\dot{m}$ - drying air mass flow rate,

$c_{p}$ - specific heat,

$T_{o}$ - temperature leaving the dryer,

$T_{i}$ - temperature entering the dryer.
The efficiency of the indirect solar dryer $(\eta)$ is expressed as (Karoua et al., 2018)

$\eta=\frac{Q_{u}}{\tau \alpha A I}$

where:

$\tau$ - covering glass optical coefficient of transmission,

$\alpha$ - thermal diffusivity of the absorber,

$A$ - total absorber area.

The relative uncertainty of the thermal efficiency is listed in Table 2.

\section{Results and discussion}

The experiments of the present work were conducted in Tikrit - Iraq $\left(34^{\circ} 40^{\prime} \mathrm{N} 43^{\circ} 39^{\prime} \mathrm{E}\right)$ form $10^{\text {th }}$ to $12^{\text {th }}$ of March 2019 from 9:00 to 15:00. The presented results are for both the proposed and conventional solar dryers for sake of comparison.

\section{Conventional indirect solar dryer}

The conventional indirect solar dryer was experimented on 10 March 2019 (9:00-15:00). The recorded solar radiation, the ambient, absorber, and the drying chamber entrance, lower space, and upper space temperatures are depicted in Figure 2. The dryer entrance temperature increased as the solar radiation increased. The highest dryer entrance temperature was $62^{\circ} \mathrm{C}$ at 12:00. Between 11:00 and 14:00, the dryer entrance temperature was ranging around $60^{\circ} \mathrm{C}$. Then it decreased after $14: 00$ as the solar radiation and ambient temperature decreased. 


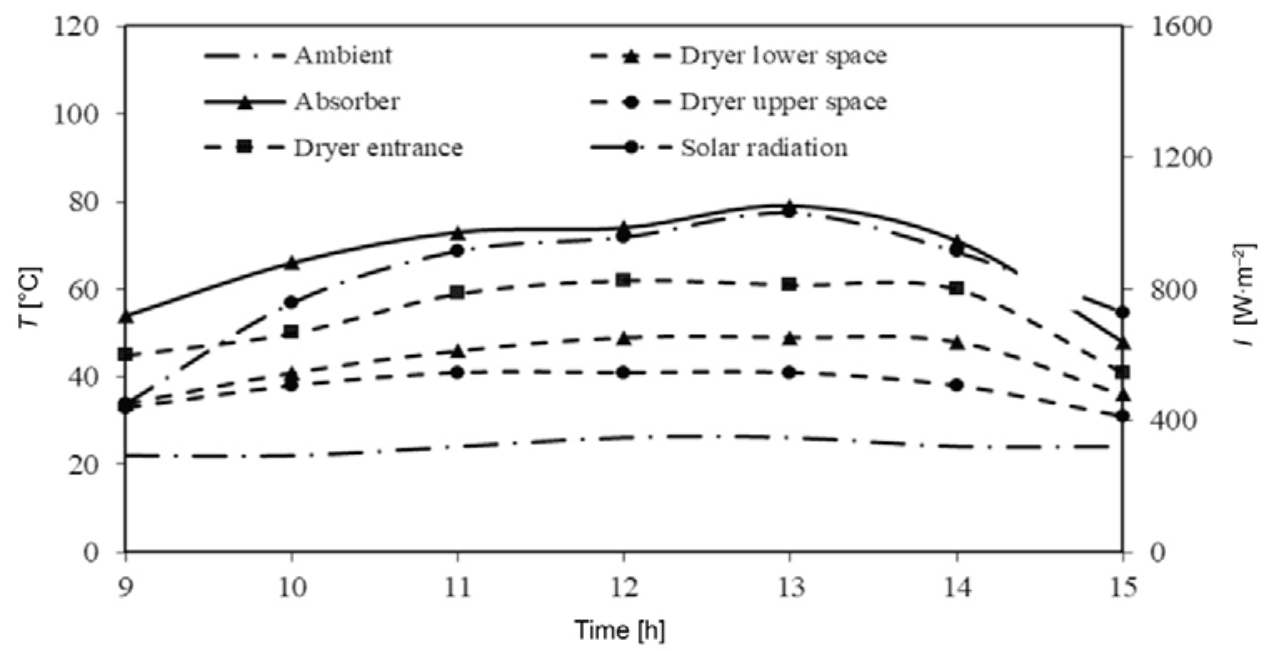

FIGURE 2. Conventional indirect solar dryer parameters

At the drying chamber lower space, the temperature raised with the solar radiation increase. The highest recorded temperature at the lower space was $49^{\circ} \mathrm{C}$ between 12:00 and 13:00. The lower space temperature was $24^{\circ} \mathrm{C}$ higher than the ambient at 14:00. The drying chamber upper space temperature increased with increasing the solar radiation and reached its highest value, i.e. $41^{\circ} \mathrm{C}$, between 11:00 and 13:00. The upper space temperature was $17^{\circ} \mathrm{C}$ higher than the ambient at 11:00. As the drying air flow along the drying chamber, its temperature decreased. The temperature difference between the lower and upper spaces was decreased up to $10^{\circ} \mathrm{C}$ at $14: 00$. This temperature difference indicates an ununiform drying environment.

\section{Novel indirect solar dryer}

The novel indirect solar dryer was experimented on 12 March 2019 (9:00$-15: 00)$. Figure 3 shows the recorded solar radiation, the ambient, absorber, and the drying chamber walls; i.e. facing the east (left), the south (front), and the west (right); temperatures besides the drying chamber entrance, lower, and upper spaces. The highest recorded temperature of the left wall was $97^{\circ} \mathrm{C}$ at 10:00, the front wall was $105^{\circ} \mathrm{C}$ at $13: 00$, and the right wall was $92^{\circ} \mathrm{C}$ at 15:00. Each wall reached its highest temperature when it was directly to the sun as the sun moved from the east to the west. The highest entrance temperature was $74^{\circ} \mathrm{C}$ at $13: 00$ when the highest solar radiation was reached. In the lower space, the highest recorded temperature was $67^{\circ} \mathrm{C}$ between 12:00 and 13:00. At the same time, i.e. between 12:00 and 13:00, also the highest temperature of the upper space was recorded, i.e. $68^{\circ} \mathrm{C}$. The air temperature difference between the entrance and the lower space was from 33 to $50^{\circ} \mathrm{C}$. This difference is due to flowing the drying air through long and large absorbing area, i.e. the solar collector. Then the drying air lost part of its heat to the connected duct between the solar collector and the drying 
a

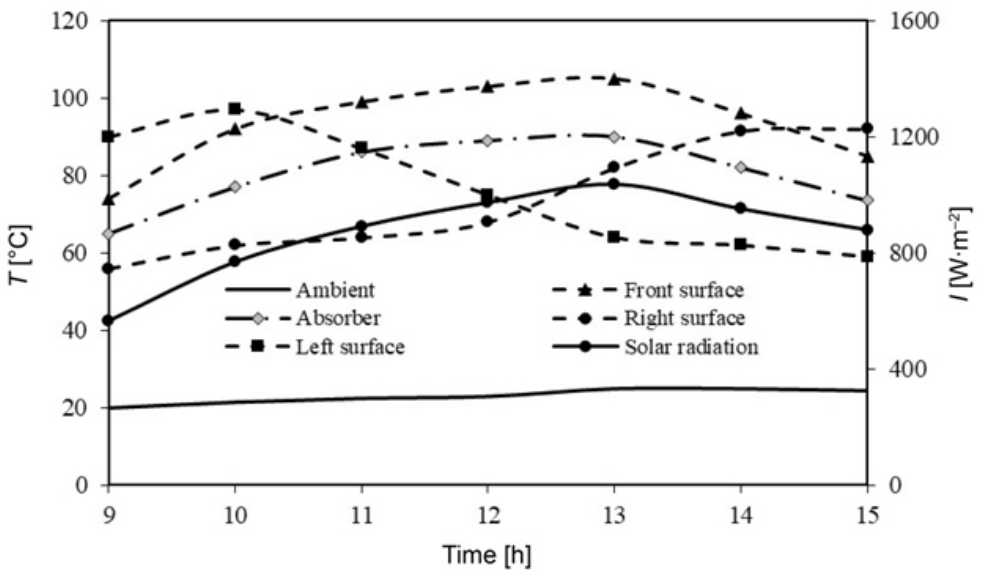

b

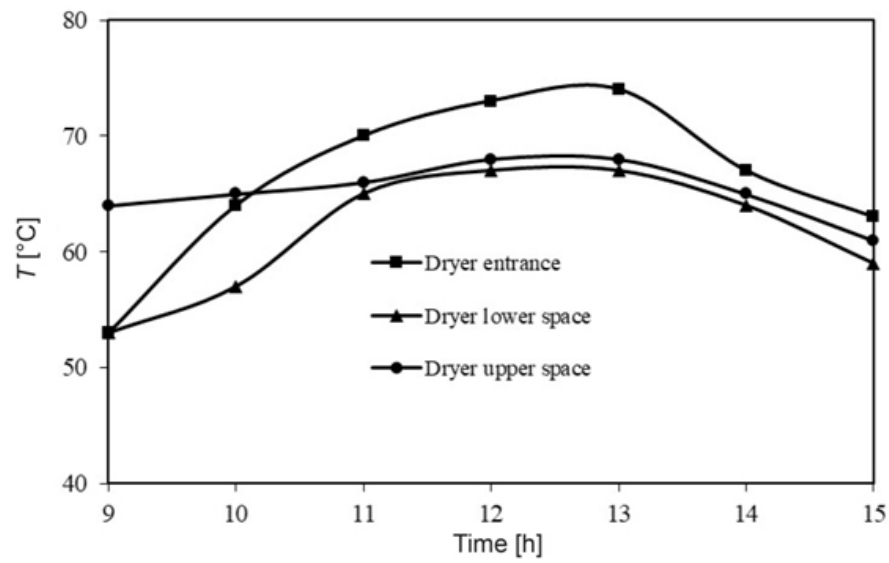

FIGURE 3. Novel indirect solar dryer parameters

chamber. At the beginning of the experiment, 9:00, the lower space temperature was $11^{\circ} \mathrm{C}$ below the upper space temperature. Two reasons caused this reduction. First, the hot drying air at the drying chamber entrance lost part of its thermal energy to the relatively cold chamber components. Second, at this early time of the day, the solar radiation was not sufficient to heat the drying chamber. With time progress, the solar radiation went up causing higher temperature at the lower space of the drying chamber. As a result, a decrease in the temperature difference between the upper and lower spaces can be noticed, i.e. $\sim 1^{\circ} \mathrm{C}$. This low temperature difference was a result of designing the left, front, and right walls of the drying chamber as solar collectors. The low temperature difference through the drying chamber offers a uniform drying.

\section{Comparison between the conventional and novel solar dryers}

Figure 4 shows a comparison between the novel and the conventional indirect solar dryers temperatures. The 


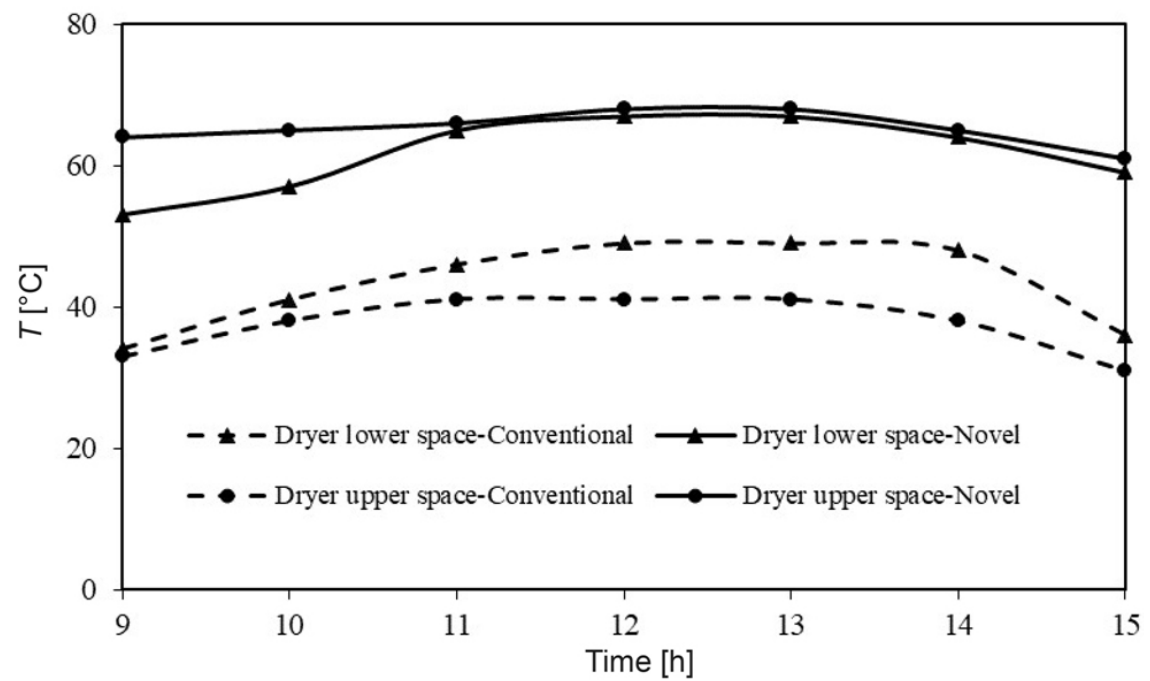

FIGURE 4. Comparison between the novel and the conventional indirect solar dryers temperatures

drying air at the entrance of the drying chamber was from 33 to $50^{\circ} \mathrm{C}(61-68 \%)$ above the ambient.

The temperature of the lower space of the novel dryer chamber was from 33 to $44^{\circ} \mathrm{C}(58-66 \%)$ above the ambient, while for the conventional dryer chamber it was from 12 to $24^{\circ} \mathrm{C}(35-50 \%)$ above the ambient. The novel dryer chamber lower space temperature was from 16 to $23^{\circ} \mathrm{C}(25-39 \%)$ above the conventional one.

The temperature of the upper space of the novel dryer chamber was from 36.5 to $45^{\circ} \mathrm{C}(60-69 \%)$ above the ambient, whereas for the conventional dryer chamber it was from 7 to $17^{\circ} \mathrm{C}$ (23-42\%) above the ambient. The novel dryer chamber upper space temperature was from 25 to $31^{\circ} \mathrm{C}(38-49 \%)$ above the conventional one.

The temperature of the drying air in the upper space of the novel dryer chamber was 1 to $11^{\circ} \mathrm{C}(1-17 \%)$ higher than that of the lower space. It should be pointed out that the low difference, i.e. $1-3 \%$, was for five hours out of seven hours of the experiment time. While for the conventional dryer, the difference between the upper and lower spaces temperature was from -10 to $-1^{\circ} \mathrm{C}$ (from -26 to $-3 \%)$.

Figure 5 shows a comparison between the novel and the conventional indirect solar dryers thermal efficiencies. The novel dryer thermal efficiency was 46-71\%, while the conventional thermal efficiency was $7-16 \%$. In other words, the novel dryer thermal efficiency was higher than that of the conventional one by $37-55 \%$. A comparison between the present work efficiencies and others from literature is tabulated in Table 3. The proposed novel solar dryer achieved the highest efficiency among the other designs.

It can be concluded that the thermal performance of the proposed design was better than that for the conventional design. 


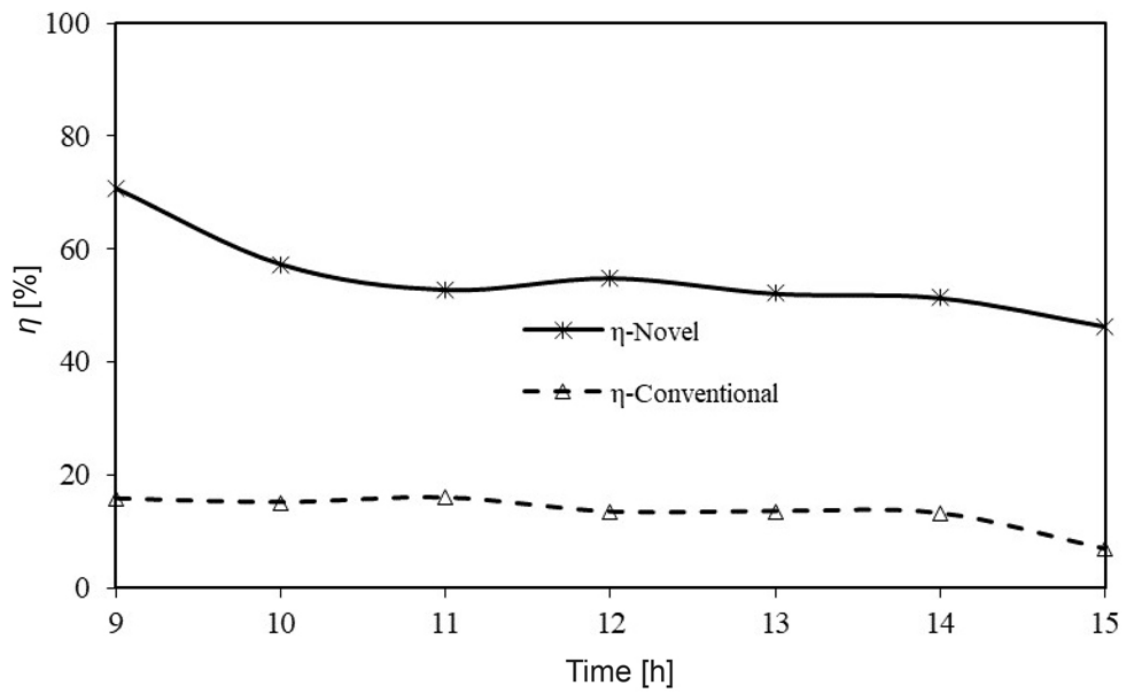

FIGURE 5. Comparison between the novel and the conventional indirect solar dryers thermal efficiencies

TABLE 3. Comparison between the present investigated solar dryers and with previous works

\begin{tabular}{|l|c|c|c|}
\hline Reference & $\begin{array}{c}\text { Average ambient } \\
\text { temperature } \\
{\left[{ }^{\circ} \mathrm{C}\right]}\end{array}$ & $\begin{array}{c}\text { Average } \\
\text { solar radiation } \\
{\left[\mathrm{W} \cdot \mathrm{m}^{-2}\right]}\end{array}$ & $\begin{array}{c}\text { Efficiency } \\
{[\%]}\end{array}$ \\
\hline Lingayat et al. (2017) & 42 & 724.0 & 31.5 \\
\hline Miri et al. (2002) & 30 & 825.0 & 40.0 \\
\hline Madhlopa, Jones and Saka (2002) & 30 & 246.5 & 21.0 \\
\hline Present conventional indirect solar dryer & 24 & 823.6 & 19.0 \\
\hline Present novel indirect solar dryer & 23 & 866.1 & 55.0 \\
\hline
\end{tabular}

\section{Conclusions}

A novel indirect solar dryer design was proposed and tested in the present experimental work. In this innovative design, besides the solar collector, three of the drying chamber walls were designed to be solar collector as well. A conventional indirect solar dryer was also tested for sake of comparison. Based on the recorded and calculated data, it can be concluded that:
- Using a solar collector elevated the temperature of the drying air at the drying chamber inlet up to $68 \%$ in the novel dryer and $60 \%$ in the conventional dryer above the ambient.

- In the novel dryer chamber lower space, the drying air was warmer than that in the conventional dryer up to $39 \%$ due to the solar collector and the drying chamber walls.

- In the novel dryer chamber upper space, the drying air was warmer 
than that in the conventional dryer up to $49 \%$ as a result of the solar collectors on the drying chamber walls.

- A thermal uniformity was achieved through the novel solar dryer, as only $3 \%$ temperature difference between the drying chamber upper space and lower space temperatures was recorded. While in the conventional solar dryer, a $-26 \%$ difference was found.

- The novel indirect solar dryer achieved a thermal efficiency of 55\% above that of the conventional one.

\section{References}

Ameri, B., Hanini, S., Benhamou, A. \& Chibane, D. (2018). Comparative approach to the performance of direct and indirect solar drying of sludge from sewage plants, experimental and theoretical evaluation. Solar Energy, 159, 722-732. https://doi.org/10.1016/ j.solener.2017.11.032

Bansal, N.K. (1987). Solar crop drying. In Phys$i c s$ and Technology of Solar Energy (pp. 413-445). Berlin: Springer.

Dheyab, H.S., Al-Jethelah, M.S.M., Yassen, T.A. \& Khalil, T. (2019). Experimental Study of The Optimum Air Gap of a Rectangular Solar Air Heater. Journal of Advanced Research in Fluid Mechanics and Thermal Sciences, 59(2), 318-329.

El-Sebaii, A.A.,Aboul-Enein, S., Ramadan, M.R.I. \& El-Gohary, H.G. (2002). Experimental investigation of an indirect type natural convection solar dryer. Energy Conversion and Management, 43(16), 2251-2266. https://doi. org/10.1016/S0196-8904(01)00152-2

Karoua, H., Moummi, A., Hamidat, A., Moummi, N., Aoues, K., Benchabane, A. \& Benchatti, A. (2018). Experimental investigation and exergy analysis of an air heater with a solar concentrator used for drying processes. International Journal of Heat and Technology, 36(3), 791-800. https://doi.org/10.18280/ ijht.360303

Lingayat, A., Chandramohan, V.P. \& Raju, V.R.K. (2017). Design, development and performance of indirect type solar dryer for banana drying. Energy Procedia, 109, 409-416. https://doi.org/10.1016/j.egypro.2017.03.041

Madhlopa, A., Jones, S.A. \& Saka, J.K. (2002). A solar air heater with composite-absorber systems for food dehydration. Renewable Energy, 27(1), 27-37.

Maiti, S., Patel, P., Vyas, K., Eswaran, K. \& Ghosh, P.K. (2011). Performance evaluation of a small scale indirect solar dryer with static reflectors during non-summer months in the Saurashtra region of western India. Solar Energy, 85(11), 2686-2696. https://doi. org/10.1016/j.solener.2011.08.007

Miri, R., Mokrani, O., Siad, F. \& Belhamel, M. (2002). Étude expérimentale d'un séchoir solaire. Revue Des Énergies Renouvelables, 2002, 41-48.

Montero, I., Blanco, J., Miranda, T., Rojas, S. \& Celma, A.R. (2010). Design, construction and performance testing of a solar dryer for agroindustrial by-products. Energy Conversion and Management, 51(7), 1510-1521. https://doi. org/10.1016/j.enconman.2010.02.009

Othieno, H., Grainger, W. \& Twidell, J.W. (1982). Application of small scale solar crop driers to maize drying in Kenya. In Energy for rural and island communities (pp. 377-386). Amsterdam: Elsevier. https://doi.org/10.1016/ B978-0-08-027606-9.50047-7

Puglia, M., Rizzo, A., Morselli, N. \& Tartarini, P. (2019). Efficiency and economical assessment of a solar powered dryer combined with a biomass gasification system. International Journal of Heat and Technology, 37(3), 705-709.

Sreekumar, A., Manikantan, P.E. \& Vijayakumar, K.P. (2008). Performance of indirect solar cabinet dryer. Energy Conversion and Management, 49(6), 1388-1395. https://doi. org/10.1016/j.enconman.2008.01.005 


\section{Summary}

Thermal performance of novel indirect passive solar dryer. An experimental investigation was conducted to study the performance of a novel indirect type free convection solar dryer. The novel and a conventional indirect passive solar dryer were built. Solar irradiation and temperature of different locations were recorded. The air at the drying chamber entrance, lower space, and upper space temperatures besides the thermal efficiency of the novel dryer were $68,39,49$ and $85 \%$, respectively, higher than the conventional one.

\section{Authors' address:}

Manar Al-Jethelah - corresponding author

(https://orcid.org/0000-0001-5383-7216)

Tadahmun Yaseen

(https://orcid.org/0000-0003-2377-6787)

Tikrit University

College of Engineering

Mechanical Engineering Department

Tikrit, Iraq

e-mail: m.aljethelah@tu.edu.iq hussam.sami@tu.edu.iq tadahmunahmed@tu.edu.iq 